\title{
Industry 4.0 and Sustainability: A Bibliometric Literature Review
}

\author{
Ana Teresa Tavares-Lehmann ${ }^{1}$ and Celeste Varum ${ }^{2, * \mathbb{D}}$ \\ 1 CEF.UP, FEP, University of Porto, 4200-464 Porto, Portugal; atavares@fep.up.pt \\ 2 GOVCOPP, DEGEIT, University of Aveiro, 3810-193 Aveiro, Portugal \\ * Correspondence: camorim@ua.pt; Tel.: +351-91-8352579
}

\begin{abstract}
Industry 4.0 (I4.0), Sustainability, and the Circular Economy are recently popularized concepts likely to redefine how economies and industries work. This paper, as the opening piece of this Special Issue, consists of a bibliometric study of 393 articles linking the Issue's key themes: Industry 4.0, Sustainability and the Circular Economy. Given that this is still a recent area of the literature, and the fact that it already commands a fast-growing number of publications, the provision of an updated overview of the relevant scientific production in the field is a relevant contribution.
\end{abstract}

Keywords: Industry 4.0; sustainability; circular economy; bibliometric; review

Citation: Tavares-Lehmann, A.T.;

Varum, C. Industry 4.0 and

Sustainability: A Bibliometric

Literature Review. Sustainability 2021,

13, 3493. https://doi.org/10.3390/ su13063493

Academic Editors: Tomás

F. Espino-Rodríguez and

Ioannis Nikolaou

Received: 31 December 2020

Accepted: 26 February 2021

Published: 22 March 2021

Publisher's Note: MDPI stays neutral with regard to jurisdictional claims in published maps and institutional affiliations.

Copyright: (c) 2021 by the authors. Licensee MDPI, Basel, Switzerland. This article is an open access article distributed under the terms and conditions of the Creative Commons Attribution (CC BY) license (https:// creativecommons.org/licenses/by/ $4.0 /)$.

\section{Introduction}

Industry 4.0 (I4.0), Sustainability, and the Circular Economy are recently popularized concepts likely to redefine how economies and industries work. There is an understanding that the combination of these concepts will propel us faster towards a Green Economy and may contribute to harmonizing ambitions for reconciling economic growth and environmental protection [1-3].

The move towards Industry 4.0 configures a move towards a new techno-economic paradigm, an ongoing movement of digital transformation of industries and value chain processes.

It has been recognized that the underlying drivers and technologies of I4.0 might help a move towards more sustainable manufacturing practices, more aligned with the view of sustainability on its three pillars, economic, social and environmental, the so-called 'triple bottom line' [4], and to fulfill the potential of the Circular Economy [5,6]. The numerous synergies between these key concepts need to be tackled and researched, and this Special Issue aims to contribute to addressing this important research topic. This Introduction, by providing a comprehensive and systematic review of the literature on these topics, is a starting point.

This paper, as the opening piece of this Special Issue, consists of a bibliometric study linking the Issue's key themes: Industry 4.0, Sustainability, and the Circular Economy. Its purpose is to provide a brief, yet very inclusive, account of the state-of-the-art of the literature linking the three topics selected as the focus of this publication.

Although the papers on this field are extremely recent-as documented later in the paper-there is an increasing number of very insightful reviews helping to structure the literature (for instance, (see [7-11]). Yet, to our knowledge, none of them follows the methodology herein used and offers such a comprehensive review of such a large base of publications. Given that this is still a recent area of the literature, and the fact that it already commands a fast-growing number of publications, the provision of an updated overview of the relevant scientific production in the field is a relevant contribution.

After this Introduction, the paper includes a section on the chosen Methodology (bibliometry), followed by the core part consisting of the application of bibliometric techniques 
and reporting of the respective results. Finally, some conclusions and avenues for future research are presented.

\section{Materials and Methods}

The methodology chosen for this paper was bibliometry, or bibliometric analysis. Pritchard (1969) is considered the author who put forward the term "bibliometrics", defining it as "the application of mathematics and statistical methods to books and other media of communication" ([12], p. 368). Over time, many definitions were proposed [13], such as the one suggested by ([14], p. 2551), who consider that bibliometric studies " (... ) use the extant published research to examine and delve into the patterns and trends of what has been published, thus helping explore, organize and make sense of the work that has been done in a certain discipline or subject of study".

Bibliometric analysis is a method that has been increasingly used in many areas of knowledge [15]. It presents advantages over the traditional literature review, as it provides a more objective and systematic selection and assessment of scientific research in a given field [13,16-18]. Bibliometry is the most appropriate methodology to identify the state-ofthe-art of literature or, as Teixeira (2014) [19] puts it, the "leading edge" of a research field. Through the application of bibliometric techniques, we were able to identify the current state of this field of knowledge and potential research gaps and knowledge boundaries [12].

The method developed by Teixeira (2014) and Archambault and Gagné (2004) [19,20] will guide the present application of bibliometric techniques. It will allow an objective assessment of the scientific output in academic publications, permitting us to identify the publications, authors, and journals that have greater impact in this area of research.

The steps performed were the following. First, the area of study was defined, focusing on Industry 4.0 and Sustainability. This step was followed by the selection of the bibliographic databases underlying the research. This step is very important to ensure a valid analysis, as such analysis depends on the quality of these databases. In this vein, two leading platforms both in terms of reputation and comprehensive content-Web of Science (WoS) and SciVerse Scopus (SCOPUS) - were selected. Such databases are multidisciplinary and display a high citation index and provide access to a vast number of publications provided by prestigious publishers such as Elsevier, Springer, and other platforms such as Google Scholar [17,21,22]. Several authors, such as $[23,24]$, extolled the virtues of such databases.

The third step involved the selection of the keywords. We conducted the search for relevant publications by using a set of directly relevant keywords, mentioned in the table below. We imposed simultaneity of the expression "Industry 4.0" and at least one keyword related to sustainability (as per Table 1 below). The search was performed in a systematic manner in the two main bibliographic databases, SCOPUS and Web of Science. The search was completed in the second week of December 2020.

Table 1 summarizes the results; 279 publications were retrieved from WoS and 329 from SCOPUS, totaling 608 publications. The next step was to remove the considerable number of duplications (215) among these two datasets, leaving a total of 393 publications to be analyzed. There were 18 publications retrieved from WoS only.

Apart from including only very specific keywords, to ensure relevance of the papers, we applied supplementary filters. One was related to language-only publications in English were analyzed.

Moreover, not all types of documents were included-only articles and reviews-as explained below. Par contre, all areas of study and related categories were included, as this paper aimed to cover research on the topic chosen in all areas. 
Table 1. Synthesis of the searches performed-keywords and bibliographic databases.

\begin{tabular}{|c|c|c|c|c|c|c|c|}
\hline \multicolumn{3}{|c|}{ Keywords: } & \multicolumn{3}{|c|}{ Bibliographic Databases } & \multirow{3}{*}{ Duplications } & \multirow{2}{*}{ Total } \\
\hline & & & WoS & SCOPUS & Both & & \\
\hline “Industry $4.0 "$ & AND & "Industrial Sustainability" & 2 & 2 & 4 & & \\
\hline "Industry $4.0 "$ & AND & "Sustainability" & 250 & 283 & 533 & & \\
\hline "Industry $4.0 "$ & AND & "Sustainability Assessments" & 0 & 3 & 3 & & \\
\hline “Industry $4.0 "$ & AND & "Circular Economy" & 67 & 70 & 137 & & \\
\hline “Industry $4.0 "$ & AND & "Green Economy" & 0 & 2 & 2 & & \\
\hline “Industry 4.0" & AND & $\begin{array}{l}\text { "Industrial Sustainability" } \\
\text { or "Sustainability" } \\
\text { or "Sustainability Assessments" } \\
\text { or "Circular Economy" } \\
\text { or "Green Economy" }\end{array}$ & 279 & 329 & 608 & 215 & 393 \\
\hline
\end{tabular}

Source: Own elaboration.

After assembling a consolidated database including both articles and reviews obtained in WoS and SCOPUS, we removed duplicates both among the datasets and also between the different keyword combination searches.

Finally, we performed the bibliometric analysis on the organized database of publications underlying this paper, extracting the trends and patterns characterizing the chosen field of study, as presented below in the results of the application of bibliometric techniques.

The analysis combines quantitative and qualitative methods. We use quantitative indicators considered very useful to understand research trends, such as the evolution over time, leading journals, publications, and authors. A content analysis complements the review, aiming to identify theoretical roots, most frequently discussed topics, as well as research gaps that may exist within the literature, which may support the identification of avenues for further research.

In order to overcome eventual limitations of this method, which could be missing the inclusion of important papers, or lack of rigor in the assembling of the final database of publications, we conducted the analysis as follows. First of all, we analyzed the two largest and most prestigious and inclusive bibliographic databases-and not just one as most studies consider sufficient. Second, we performed a variety of searches on smaller databases and overall on the internet to see if relevant publications were not included. We did not find any relevant publication that was not already captured by the two comprehensive databases used. In terms of rigor in the inclusion of relevant papers, instead of conducting only an analysis of the titles and of the abstracts, we did review the whole text of all the documents included, hence guaranteeing their relevance and appropriateness to the final database of articles underlying the analyzes that follow.

Table 1 below offers a synthesis of the searches performed, identifying the relevant keywords and the number of publications per database and then the final number of papers thoroughly analyzed, after removing duplicates. The keywords strictly follow the key topics underlying this Special Issue.

\section{Results}

This part reports on the results from the analysis of the data gathered from the bibliometric analysis. It first offers a brief characterization of the types and categories of the publications and then a deeper exploration of the main trends and patterns of the reviewed literature on Industry 4.0 and Sustainability. The results cover a chronological account of the literature, the main journals and authors publishing in the field, the articles and reviews with more influence within the literature, as well as an analysis of the main topics of the literature. 


\subsection{Type of Publications and Respective Categories (Areas) of the Publications}

The vast majority of the 393 publications included in this study were articles (323, representing $82 \%$ of the total), and 70 were reviews (18\% of the total) (Figure 1$)$.

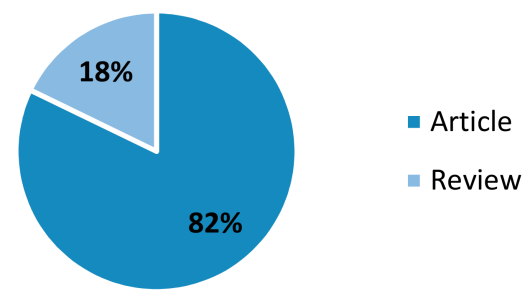

Figure 1. Types of Publications, Source: Own elaboration.

It was decided to include only these two types of publications as they are peerreviewed, being subject to the scrutiny of other scientific experts in the same field, thus offering greater guarantees of rigor than other types of publications [25].

Reviews on the topic surged lately [26] and are of particular interest as they summarize research on different aspects within the field under study.

Figure 2 below analyzes the distinct categories to which the publications under scrutiny belong. As we reviewed publications from two bibliographic databases, there was a need to opt for a breakdown of categories used in one of them. Hence, we chose the categories from Scopus (considering that Scopus had more observations). The corresponding categories from WoS were adapted to similar SCOPUS categories in order to guarantee uniformity.

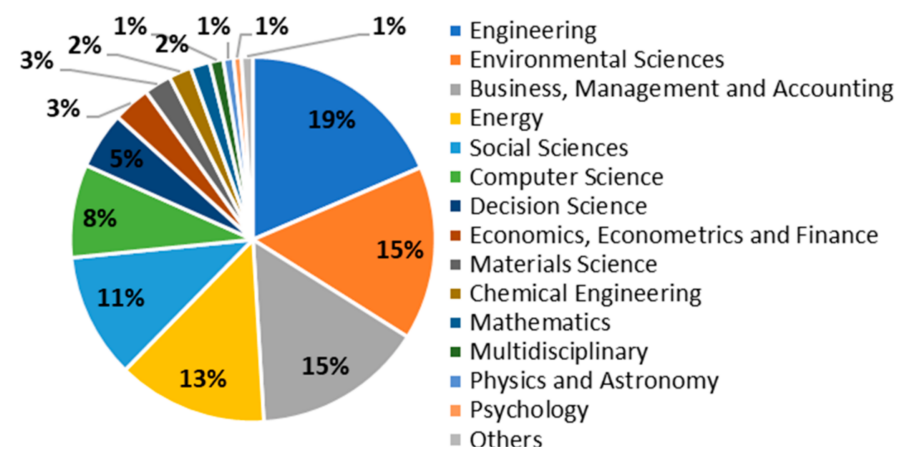

Figure 2. Categories (areas) of the publications. Source: Own elaboration.

The category with the most observations (19\% of the total) was "Engineering", which is not surprising considering that "Industry 4.0 " was a keyword present in all searches, and engineering is a prime area related to Industry 4.0. The second and third categories (ex aequo) with high numbers of publications were "Environmental Sciences (15\%) and "Business, Management, and Accounting" (15\%). Thus, we can observe the relevance of three key areas (together representing $49 \%$ of the total of publications considered): Engineering, Environmental Sciences, and Business/ Management.

After that, the categories that were the most common were "Energy" (13\%), "Social Sciences" (11\%), "Computer Science (8\%), and "Decision Science" (5\%). These seven categories included $86 \%$ of all observations.

In all, if we form key groups, we observe a prevalence of four key broad areas of knowledge: (i) Engineering; (ii) Environment; (iii) Business/Economics; (iv) Decision Sciences/Computer Science /Maths, other areas being residual. This makes sense considering the inclusion of Industry 4.0 and the "triple bottom line" [4] of Sustainability (Economic, Environmental, and Social). 


\subsection{Main Trends of the Reviewed Literature}

In what concerns the main trends of the literature, in what follows we refer to the chronological evolution of the literature, to the most influential journals where research on the surveyed themes was present, to the most cited publications and authors, and to the main themes analyzed in the surveyed literature.

\subsubsection{Chronological Evolution of the Literature}

An analysis of Figure 3 suggests we are in the presence of a new field of research that experienced a boom in the last 3-4 years. The first article included in the datasets is from 2015. The growing trend is undeniable. The year with the most publications was 2020 (218 references), followed by 2019 (96 publications). This makes the present analysis timely and justified given the exponential increase in articles in the last couple of years.

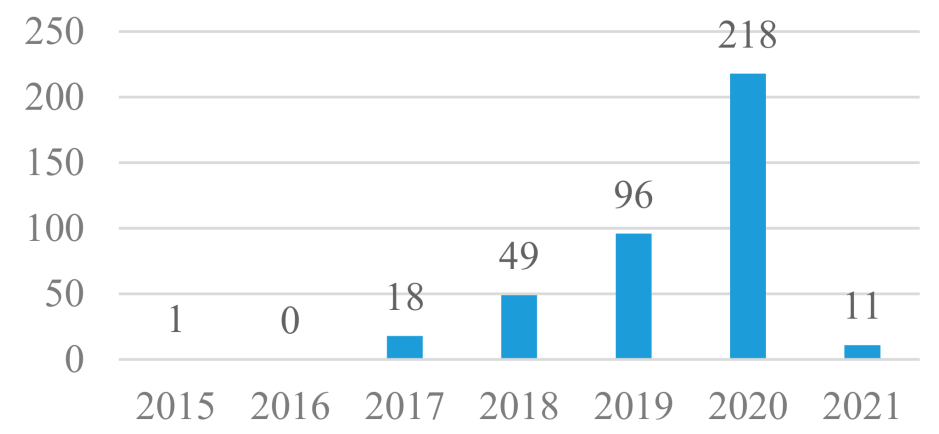

Figure 3. Chronological Evolution of the Literature. Source: Own elaboration.

The next step was to classify the number of publications by type of analysis: (i) Theoretical; (ii) Empirical; or (iii) Mixed (Figure 4). In total, 176 publications were Empirical $(45 \%), 173$ were theoretical $(44 \%)$, and $44(11 \%)$ were mixed (i.e., including both a theoretical and an empirical component). Hence, we can observe a very even distribution between theoretical and empirical contributions.

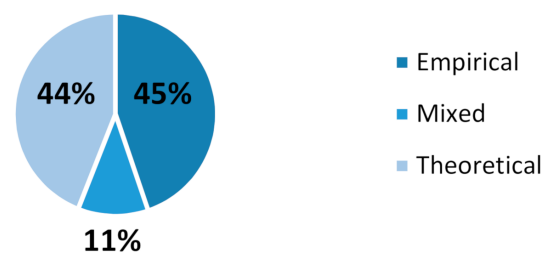

Figure 4. Number of articles or reviews by type of analysis. Source: Own elaboration.

\subsubsection{Top Journals per Number of Publications (per Year)}

Another very important element characterizing the sample consisted of identifying the most influential journals where research on the surveyed themes was present.

Table 2 below summarizes the relevant findings.

Overall, the publications considered were distributed among 160 different journals. Among these 160 journals, we considered the top 24 journals (with three or more publications), accounting for $59.5 \%$ of the total publications (393) of our database.

The leading journal in this ranking of the number of observations was Sustainability, with 81 publications. A distant second place was occupied by the Journal of Cleaner Production, with 27 articles, followed by the International Journal of Production Research with 12 publications, and then Resources, Conservation, and Recycling (11 publications).

Table 2 below includes a ranking of the journals with high numbers of publications overall and a breakdown of the number of publications per year. 
Table 2. Top journals per number of publications (per year).

\begin{tabular}{|c|c|c|c|c|c|c|c|c|}
\hline \multirow{2}{*}{ Journal } & \multicolumn{5}{|c|}{ Year } & \multirow{2}{*}{ Total } & \multirow{2}{*}{$\begin{array}{c}\text { SJR } \\
(2019)\end{array}$} & \multirow{2}{*}{ Category } \\
\hline & 2017 & 2018 & 2019 & 2020 & 2021 & & & \\
\hline Sustainability & 3 & 11 & 19 & 48 & & 81 & 0.58 & EIESISS \\
\hline Journal of Cleaner Production & & 2 & 3 & 19 & 3 & 27 & 1.189 & BMA $|E| E n \mid E S$ \\
\hline International Journal of Production Research & & & 3 & 9 & & 12 & 1.78 & BMA |DSIEn \\
\hline Resources, Conservation and Recycling & & & 2 & 7 & 2 & 11 & 2.22 & EEFIES \\
\hline Journal of Manufacturing Technology Management & & 2 & 2 & 5 & & 9 & 1.17 & BMA ICS I En \\
\hline Production Planning and Control & & & 1 & 7 & 1 & 9 & 1.39 & BMA ICS IEn IDS \\
\hline Technological Forecasting and Social Change & & 2 & 1 & 3 & 1 & 7 & 1.82 & BMA $\mid \mathrm{P}$ \\
\hline Benchmarking & & & 5 & 1 & & 6 & 0.55 & BMA \\
\hline Computers in Industry & & & 2 & 4 & & 6 & 1.01 & CSIEn \\
\hline IEEE Access & & 1 & 2 & 3 & & 6 & 0.78 & CSIEn IMS \\
\hline IFAC-PapersOnLine & & 3 & 3 & & & 6 & 0.33 & En \\
\hline Process Safety and Environmental Protection & & 6 & & & & 6 & 1.1 & CEIEn|ES \\
\hline Applied Sciences & & 1 & 1 & 3 & & 5 & 0.42 & CE IEn ICS I MS \\
\hline Energies & & 1 & 1 & 3 & & 5 & 0.64 & ElEn $\mid M$ \\
\hline Entrepreneurship and Sustainability Issues & 1 & & 2 & 2 & & 5 & 1.17 & BMA | EEF | ES \\
\hline International Journal of Production Economics & & & & 4 & 1 & 5 & 2.38 & BMA | DS I EEF | En \\
\hline Computers and Industrial Engineering & & 1 & 1 & 2 & & 4 & 1.47 & CSIEn \\
\hline International Journal of Supply Chain Management & & & 3 & 1 & & 4 & 0.19 & BMA ICS IDS \\
\hline Tehnicki Glasnik-Technical Journal & & & 2 & 2 & & 4 & $\mathrm{n} / \mathrm{a}$ & $\mathrm{n} / \mathrm{a}$ \\
\hline Journal of Modelling in Management & & & 1 & 2 & & 3 & 0.57 & BMA IDS \\
\hline Procedia Manufacturing & 3 & & & & & 3 & 0.52 & CSIEn \\
\hline Processes & & & 1 & 2 & & 3 & 0.4 & $\mathrm{CE}$ \\
\hline TECHNE & 1 & & 2 & & & 3 & 0.17 & En ISS \\
\hline TQM Journal & & & & 3 & & 3 & 0.66 & BMA IDC \\
\hline
\end{tabular}

Source: Own elaboration. E-Energy; ES-Environmental Sciences; SS-Social Sciences; BMA-Business, Management, and Accounting; En-Engineering; DS-Decision Sciences; EEF-Economics, Econometrics, and Finance; CS-Computer Sciences; P-Psychology; M-Mathematics. SJR: Scientific Journal Rankings.

The table also reports, for each journal, the SJR (2019) indicator-a quantitative tool developed by SCOPUS that ranks and evaluates the journals based on the citations from the year under analysis, divided by the previous three years' publications (including articles, reviews, and conference papers) [27]. Therefore, once SJR's ranking has been normalized to account for journals from different fields of studies [28], this indicator enables us to understand the relevance of these journals for their field of study. These journals gather information from different subject areas, also presented in the table below.

Overall, the journals that have a higher SJR are the International Journal of Production Economics, with an impact factor of 2.38, followed by the Resources, Conservation, and Recycling, with an impact factor of 2.22. Within the categories of these journals, Economics, Econometrics, and Finance (EEF) and Business, Management, and Accounting (BMA) were the categories that mostly contributed to these respective impact factors.

\subsubsection{Ranking of Authors per Number of Publications}

Our sample includes the work of 1232 authors, both alone and in co-authorship. The number of authors per article or review varies from one to six. Table 3 contains the authors that wrote three or more articles or reviews. 
Table 3. Ranking of authors per number of publications.

\begin{tabular}{cccccc}
\hline Rank & Author's Name & Number of Publications & Rank & Author's Name & Number of Publications \\
\hline 1 & Luthra S. & 6 & 19 & Wood L.C. & 3 \\
2 & Bag S. & 6 & 20 & Strandhagen J.O. & 3 \\
3 & Müller J.M. & 5 & 21 & Bányai T. & 3 \\
4 & Mangla S.K. & 5 & 22 & Illés B. & 3 \\
5 & Voigt K.-I. & 4 & 23 & Kumar R. & 3 \\
6 & Garza-Reyes J.A. & 4 & 24 & Tsai W.-H. & 3 \\
7 & Singh S.P. & 4 & 25 & Yadav G. & 3 \\
8 & Ghobakhloo M. & 4 & 26 & Azizi A. & 3 \\
9 & Matt D.T. & 4 & 27 & Sarkis J. & 3 \\
10 & Rauch E. & 4 & 28 & Batista M. & 3 \\
11 & Fathi M. & 4 & 30 & Ramirez-Peña M. & 3 \\
12 & Chauhan C. & 3 & 31 & Salah B. & 3 \\
13 & Jabbour C.J.C. & 3 & 32 & Gupta S. & 3 \\
14 & Gunasekaran A. & 3 & 33 & Khan M.A. & 3 \\
15 & Garrido-Hidalgo C. & 3 & Trentesaux D. & 3 \\
16 & Olivares T. & 3 & 35 & Singh R.K. & 3 \\
17 & Ferrari A.M. & 3 & 36 & Dwivedi Y.K. & \\
\hline
\end{tabular}

If we look at the number of publications per author, we must highlight the contribution of Luthra and Bag to our research field. The articles and reviews of these two authors were mostly published in the top 20 journals, presented in Table 2, notably the journal Sustainability, the Journal of Cleaner Production and the journal Entrepreneurship and Sustainability Issues. As for their contribution to this research field, Luthra, in co-authorship with many authors, such as Mangla S.K. (in the 4th position of the ranking presented below) and Chauhan (in the 12th position), explored the relationship between I4.0 and enterprise performance, as well as the impact of I4.0 on supply chain sustainability, with a specific focus on emerging economies (see [29-31]). As for the papers published by Bag et al., their main focus was I4.0 and the circular economy (see [32]), and we must highlight the empirical paper from 2020 developed both by Bag and Luthra, in co-authorship with other reference authors, entitled "Procurement 4.0 and its implications on business process performance in a circular economy" published in the journal Entrepreneurship and Sustainability Issues (see [33]). Müller and Voigt also contributed to our research field, mostly focusing on the implementation of I4.0 in the context of sustainability and sustainable value creation, with highly cited publications (such as [34-36]).

\subsubsection{Most Cited Articles and Reviews}

Top 20 Articles and Reviews Based on Their Number of Citations

One of the most relevant aspects to study in a bibliometric review of the performance of the literature is the analysis of the most cited publications [37].

Table 4 presents the most influential 20 articles and reviews based on their number of citations.

Table 4. Top 20 articles and reviews based on their number of citations.

\begin{tabular}{clccc}
\hline Rank & \multicolumn{1}{c}{ Article or Review } & \multicolumn{1}{c}{ Authors } & Year & \multicolumn{1}{c}{ Journal } \\
\hline 1 & $\begin{array}{l}\text { Sustainable Industry 4.0 framework: } \\
\text { A systematic literature review } \\
\text { identifying the current trends and } \\
\text { future perspectives }\end{array}$ & $\begin{array}{l}\text { Kamble, Gunasekaran } \\
\text { and Gawankar }\end{array}$ & 2018 & $\begin{array}{l}\text { Process Safety and } \\
\text { Environmental Protection }\end{array}$ \\
\hline & $\begin{array}{l}\text { What drives the implementation of } \\
\text { Industry 4.0? The role of } \\
\text { opportunities and challenges in the } \\
\text { context of Sustainability }\end{array}$ & Müller, Kiel and Voigt & 2018 & Sustainability \\
\hline
\end{tabular}


Table 4. Cont.

\begin{tabular}{|c|c|c|c|c|c|}
\hline Rank & Article or Review & Authors & Year & Journal & Citations \\
\hline 3 & $\begin{array}{l}\text { Industry } 4.0 \text { and the circular } \\
\text { economy: a proposed research } \\
\text { agenda and original roadmap for } \\
\text { sustainable operations }\end{array}$ & $\begin{array}{l}\text { de Sousa Jabbour, } \\
\text { Jabbour, Godinho } \\
\text { Filho and Roubaud }\end{array}$ & 2018 & $\begin{array}{l}\text { Annals of Operations } \\
\text { Research }\end{array}$ & 155 \\
\hline 4 & $\begin{array}{l}\text { When titans meet-Can industry } 4.0 \\
\text { revolutionise the } \\
\text { environmentally-sustainable } \\
\text { manufacturing wave? The role of } \\
\text { critical success factors }\end{array}$ & $\begin{array}{l}\text { de Sousa Jabbour, } \\
\text { Jabbour, Foropon and } \\
\text { Filho }\end{array}$ & 2018 & $\begin{array}{l}\text { Technological Forecasting } \\
\text { and Social Change }\end{array}$ & 141 \\
\hline 5 & $\begin{array}{l}\text { Sustainable industrial value creation: } \\
\text { Benefits and challenges of industry } \\
4.0\end{array}$ & $\begin{array}{l}\text { Kiel, Müller, Arnold } \\
\text { and Voigt }\end{array}$ & 2017 & $\begin{array}{l}\text { International Journal of } \\
\text { Innovation Management }\end{array}$ & 140 \\
\hline 6 & $\begin{array}{l}\text { Evaluating challenges to Industry } 4.0 \\
\text { initiatives for supply chain } \\
\text { sustainability in emerging economies }\end{array}$ & Luthra and Mangla & 2018 & $\begin{array}{l}\text { Process Safety and } \\
\text { Environmental Protection }\end{array}$ & 119 \\
\hline 7 & $\begin{array}{l}\text { Industry } 4.0 \text { in Management Studies: } \\
\text { A Systematic Literature Review }\end{array}$ & $\begin{array}{l}\text { Piccarozzi, Aquilani } \\
\text { and Gatti }\end{array}$ & 2018 & Sustainability & 100 \\
\hline 8 & $\begin{array}{l}\text { Industry } 4.0 \text { and Sustainability } \\
\text { implications: A scenario-based } \\
\text { analysis of the impacts and } \\
\text { challenges }\end{array}$ & $\begin{array}{l}\text { Bonilla, Silva, da Silva, } \\
\text { Gonçalves and } \\
\text { Sacomano }\end{array}$ & 2018 & Sustainability & 94 \\
\hline 9 & $\begin{array}{l}\text { The role and impact of industry } 4.0 \\
\text { and the internet of things on the } \\
\text { business strategy of the value } \\
\text { chain-the case of Hungary }\end{array}$ & $\begin{array}{l}\text { Nagy, Oláh, Erdei, } \\
\text { Máté and Popp }\end{array}$ & 2018 & Sustainability & 93 \\
\hline 10 & $\begin{array}{l}\text { Exploring how usage-focused } \\
\text { business models enable circular } \\
\text { economy through digital technologies }\end{array}$ & $\begin{array}{l}\text { Bressanelli, } \\
\text { Adrodegari, Perona } \\
\text { and Saccani }\end{array}$ & 2018 & Sustainability & 83 \\
\hline 11 & $\begin{array}{l}\text { Industry } 4.0 \text { as enabler for a } \\
\text { sustainable development: A } \\
\text { qualitative assessment of its } \\
\text { ecological and social potential }\end{array}$ & $\begin{array}{l}\text { Stock, Obenaus, } \\
\text { Kunz and Kohl }\end{array}$ & 2018 & $\begin{array}{l}\text { Process Safety and } \\
\text { Environmental Protection }\end{array}$ & 83 \\
\hline 12 & $\begin{array}{l}\text { A review of Internet of Things (IoT) } \\
\text { embedded sustainable supply chain } \\
\text { for industry } 4.0 \text { requirements }\end{array}$ & $\begin{array}{l}\text { Manavalan and } \\
\text { Jayakrishna }\end{array}$ & 2019 & $\begin{array}{l}\text { Computers and Industrial } \\
\text { Engineering }\end{array}$ & 80 \\
\hline 13 & $\begin{array}{l}\text { Exploring Industry } 4.0 \text { technologies } \\
\text { to enable circular economy practices } \\
\text { in a manufacturing context: A } \\
\text { business model proposal }\end{array}$ & $\begin{array}{l}\text { Nascimento, } \\
\text { Alencastro, Quelhas, } \\
\text { Caiado, Garza-Reyes, } \\
\text { Lona and Tortorella }\end{array}$ & 2019 & $\begin{array}{l}\text { Journal of Manufacturing } \\
\text { Technology Management }\end{array}$ & 76 \\
\hline 14 & $\begin{array}{l}\text { Assessing challenges for } \\
\text { implementing Industry } 4.0 \text { : } \\
\text { Implications for process safety and } \\
\text { environmental protection }\end{array}$ & $\begin{array}{l}\text { Moktadir, Ali, } \\
\text { Kusi-Sarpong and } \\
\text { Shaikh }\end{array}$ & 2018 & $\begin{array}{l}\text { Process Safety and } \\
\text { Environmental Protection }\end{array}$ & 69 \\
\hline 15 & $\begin{array}{l}\text { Development of a risk framework for } \\
\text { Industry } 4.0 \text { in the context of } \\
\text { Sustainability for established } \\
\text { manufacturers }\end{array}$ & $\begin{array}{l}\text { Birkel, Veil, Müller, } \\
\text { Hartmann and Voigt }\end{array}$ & 2019 & Sustainability & 66 \\
\hline 16 & $\begin{array}{l}\text { Sustainable Industrial Value Creation } \\
\text { in SMEs: A Comparison between } \\
\text { Industry } 4.0 \text { and Made in China } 2025\end{array}$ & Müller and Voigt & 2018 & $\begin{array}{l}\text { International Journal of } \\
\text { Precision Engineering and } \\
\text { Manufacturing-Green } \\
\text { Technology }\end{array}$ & 60 \\
\hline
\end{tabular}


Table 4. Cont.

\begin{tabular}{|c|c|c|c|c|c|}
\hline Rank & Article or Review & Authors & Year & Journal & Citations \\
\hline 17 & $\begin{array}{l}\text { On sustainable production networks } \\
\text { for industry } 4.0\end{array}$ & Prause and Atari & 2017 & $\begin{array}{l}\text { Entrepreneurship and } \\
\text { Sustainability Issues }\end{array}$ & 54 \\
\hline 18 & $\begin{array}{l}\text { Sustainable manufacturing in } \\
\text { Industry } 4.0 \text { : an emerging research } \\
\text { agenda }\end{array}$ & $\begin{array}{l}\text { Machado, Winroth } \\
\text { and Ribeiro da Silva }\end{array}$ & 2020 & $\begin{array}{l}\text { International Journal of } \\
\text { Production Research }\end{array}$ & 49 \\
\hline 19 & $\begin{array}{l}\text { Linking big data analytics and } \\
\text { operational sustainability practices } \\
\text { for sustainable business management }\end{array}$ & $\begin{array}{l}\text { Raut, Mangla, } \\
\text { Narwane, Gardas, } \\
\text { Priyadarshinee and } \\
\text { Narkhede }\end{array}$ & 2019 & $\begin{array}{l}\text { Journal of Cleaner } \\
\text { Production }\end{array}$ & 49 \\
\hline 20 & $\begin{array}{l}\text { Smart manufacturing technology, } \\
\text { market maturity analysis, } \\
\text { and technology roadmap in the } \\
\text { computer and electronic product } \\
\text { manufacturing industry }\end{array}$ & Lu and Weng & 2018 & $\begin{array}{l}\text { Technological Forecasting } \\
\text { and Social Change }\end{array}$ & 48 \\
\hline
\end{tabular}

There were seven publications with 100 or more citations. Considering that these articles are relatively recent, the number of citations is quite surprising.

The two most cited articles, with 179 and 177 citations, respectively, are "Sustainable Industry 4.0 framework: A systematic literature review identifying the current trends and future perspectives" (2018), by Kamble, Gunasekaran and Gawankar (published in the Journal Process Safety and Environmental Protection) [7], and "What drives the implementation of Industry 4.0? The role of opportunities and challenges in the context of Sustainability" (2018), by Müller, Kiel and Voigt, published in Sustainability [34].

\section{Network Overlay of the Most Cited Journal Articles or Reviews}

After clarifying the ranking just presented, we studied the network overlay of the most cited journal articles and reviews. By analyzing the citation link of the documents, we were able to identify which articles or reviews cited other articles or reviews within the same set of documents. The figure below presents such a network overlay, including the journal articles and reviews that were cited 25 or more times. Although 56 papers were cited more than 25 times, we were only able to find connections between 40 of them-meaning that within the top 56 papers, 40 of them cited other papers of the set of papers under analysis (56). This figure was retrieved from the software VOS viewer.

Figure 5 illustrates the links between the most cited journal articles and reviews as well as the different clusters created within the set of documents (represented by the different colors; the larger the circle, the higher the number of citations).

Overall, nine clusters were defined, represented by the different colors within Figure 5. We must highlight that the most cited article, entitled "Sustainable Industry 4.0 framework: A systematic literature review identifying the current trends and future perspectives" [7], is linked to two other highly cited publications- the article developed by de Sousa Jabbour, Jabbour, Foropon, and Godinho Filho in 2018 (in the 4th position of Table 3) and the one published by Luthra and Mangla in 2018 (in the sixth position of Table 3). This cluster is represented in orange in Figure 5.

Another cluster of highly relevant publications is represented in green in the figure above, containing the most cited publication from Müller and Voigt, with two links to other publications, notably the one by Machado, Winroth, and Ribeiro da Silva, in 2020, exploring the correlation between sustainable manufacturing and I4.0 (18th position).

In blue, we have another cluster, including the papers published by Piccarozzi, et al. (7th position) and Bonilla, et al. (8th position). We must highlight that the papers from this cluster were all published in the journal Sustainability. 


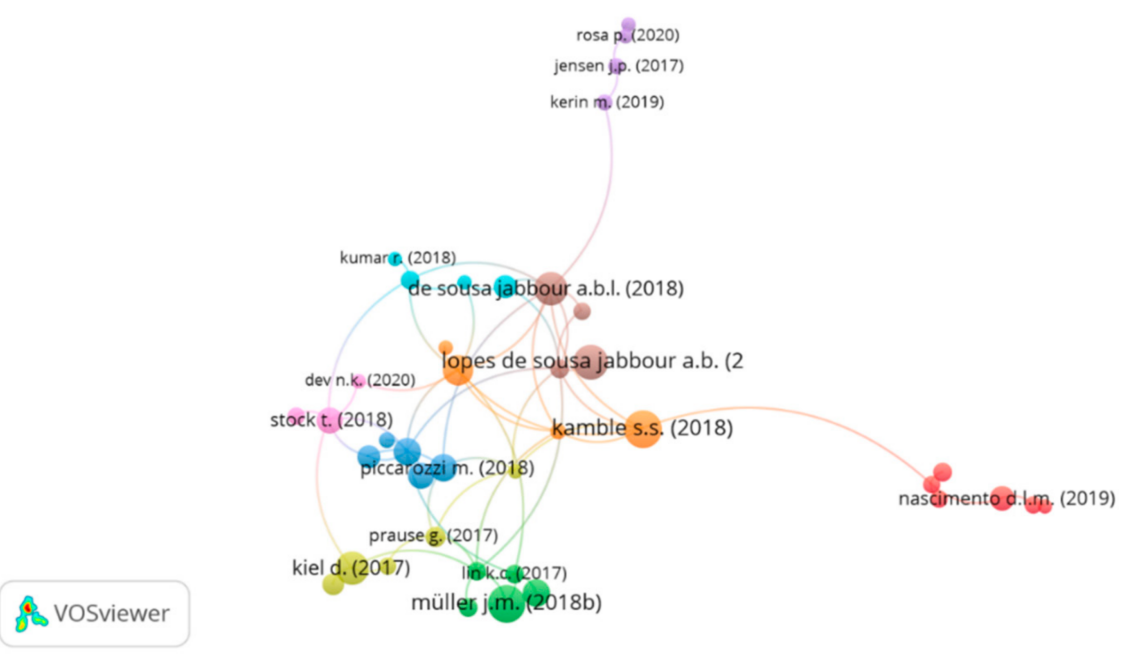

Figure 5. Network overlay of the most cited journal articles or reviews. Source: Own elaboration, using the software VOS viewer.

Although many clusters were identified, they all have in common the subjects under analysis: I4.0 and the circular economy, as well as the impact of i4.0 technologies in sustainable manufacturing.

\subsubsection{Main Topics}

The keywords were retrieved from VOS viewer and were not "homogenized", i.e., such keywords were extracted exactly and objectively as they were identified. Figure 6 includes all keywords that were mentioned 10 or more times (64 keywords). Overall, we obtained 2586 keywords (authors keywords and indexed keywords). On average, each article or review had between 6 and 7 (6.58) keywords.
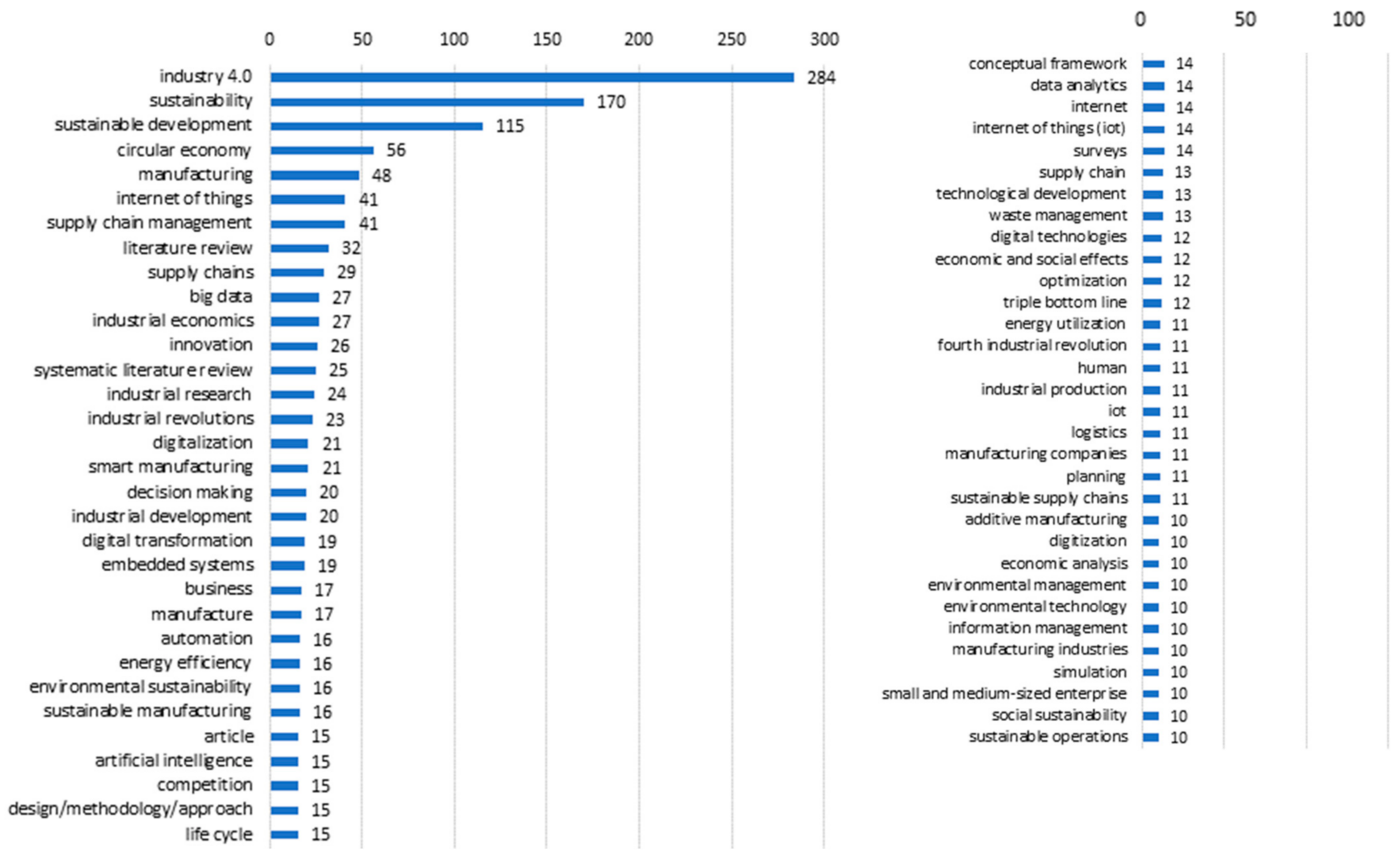

Figure 6. Frequency of keywords (topics) mentioned in the publications. Source: Own elaboration. 
The Most Frequent Keywords (Topics) Mentioned in the Reviewed Publications

As expected, the range of topics was very broad being that the three most frequent topics (keywords) mentioned in the reviewed literature were "Industry 4.0" (284 occurrences), "Sustainability" (170), and "Sustainable development" (115) followed by "Circular economy" (56), "Manufacturing" (48), Internet of Things (41), and "Supply Chain Management" (41). Figure 6 demonstrates the keywords that had 10 or more occurrences within our database.

Network Overlay of Most Frequent Keywords (10 or More Occurrences)

The graphical analysis of the network overlay of the keywords (Figure 7) shows that under the diversity of themes under analysis it is possible to identify four large groups.

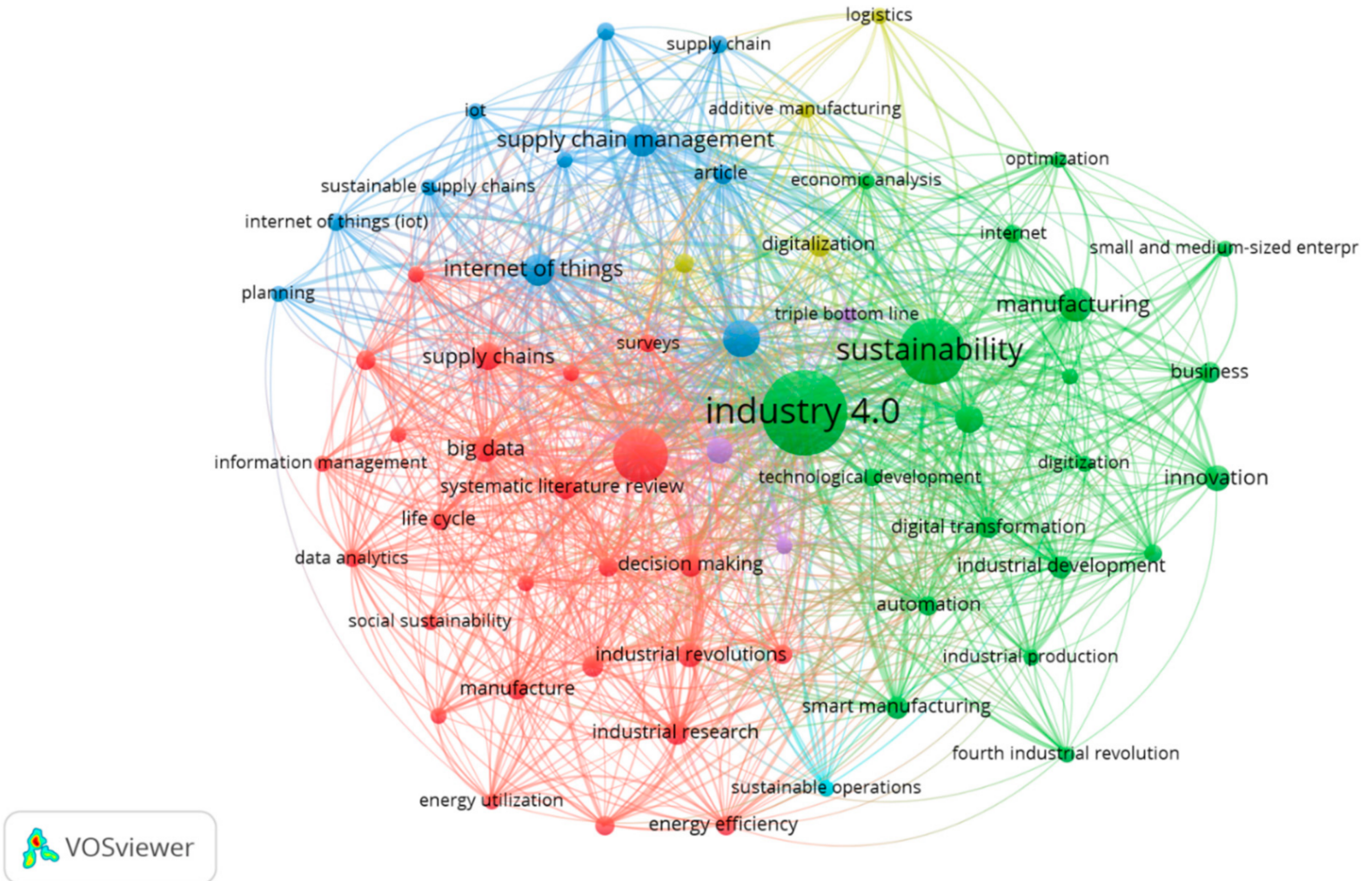

Figure 7. Network overlay of the most frequent keywords. Source: Own elaboration.

The first group, represented in green, is focused on Industry 4.0 in general, as well on sustainability, also revealing the concern with business impacts and industrial development. In this context, some highly cited articles presented in Table 3 stand out, notably the review by Kamble et al. [7], aimed to develop a sustainable I4.0 framework. According to these authors, Industry 4.0 is a key factor in increasing the quality and performance of an organization, as well as sustainability. The literature also highlights how smart machines improve business and that smaller enterprises can also have access to this technology, as advanced by Müller et al. [34]. This article explores the opportunities and challenges for companies when adopting i4.0 in the context of sustainability. The review by Piccarozzi et al. [10] supports companies to better understand the implications and scope of the 4th industrial revolution. It is evident from this literature that while many organizations might still have doubts about how Industry 4.0 could impact their business, several others are implementing changes today and preparing for the future. Moreover, this group of studies also enters into de emerging discussion on how i4.0 may contribute to sustainability.

The second group, represented in red, shows systematic literature reviews and surveys and highlights the role of big data, cloud computing, and advanced data analytics, 
with (related) artificial intelligence, where innovative data exchange models also play a key role. It is stated that data analytics is becoming a very popular concept in academia as well as in industry [38]. In this regard, Bressanelli et al. [6] focus on the Internet of Things (IoT), Big Data, and analytics and identify eight specific functionalities enabled by such technologies, which support the implementation of the circular economy (CE) paradigm into businesses, and explore how digital technologies are contributing to the development of servitized business models. Studies within this scope discuss 'the next generation of manufacturing systems' [39] and a new wave of manufacturing innovation [22,40].

The third group is focused upon supply chain management, logistics, and IOT, being the latter a key component of industry 4.0. A notable contribution on this regard is the article by Manavalan and Jayakrishna [41], who conducted a review of the Internet of Things (IoT) embedded in a sustainable supply chain for industry 4.0 requirements. Luthra and Mangla [29] is another case in point, evaluating challenges to industry 4.0 initiatives for supply chain sustainability in emerging economies. Ding [42] also conducted a review and identifies research opportunities in sustainable pharmaceutical supply chains, while Yadav et al. [43] advanced a framework to overcome sustainable supply chain challenges through solution measures of industry 4.0 and circular economy in the automotive industry. Others focus on logistics, namely, on Logistics 4.0, as an element of Industry 4.0. Strandhagen et al. [44] discussed the advantages of 'reverse logistics system' in real-time mode [45].

The fourth and final group, less intense, was focused on additive manufacturing. This literature discusses the advantages and limitations of additive manufacturing, arguing that manufacturing (AM) 'has introduced a novel production method in design, manufacturing, and distribution to end-users'. Furthermore, the advantages and hurdles of AM are also discussed, and it is argued that 'this technology has provided great freedom in design for creating complex components, highly customizable products, and efficient waste minimization' [46-48].

\section{Conclusions}

This paper, which introduces this Special Issue on Industry 4.0 and Industrial Sustainability, aimed to provide a systematic and comprehensive account of the state-of-the-art of the literature on these topics.

Using a rigorous and well-accepted methodology, the paper developed a wide-ranging bibliometric study of extant literature. The methodology employed, explained in detail in Section 2 above, allows an objective assessment of the scientific output on the relevant topics, in several dimensions. The research reported in this paper relied on 393 articles linking these Issue's key themes, extracted from the two main and most inclusive bibliographic databases (Web of Science and SciVerse Scopus). These papers were subject to quantitative treatment and to an extensive and detailed content analysis, of which a synthesis is provided in this work.

This large-scale analysis of the relevant literature led us to reach the following conclusions.

First of all, different scientific areas demonstrate an interest in these themes. The four most frequent areas are Engineering; Environmental Sciences; Business, Management and Accounting; Energy; Decision \& Computer Sciences; and Social Sciences.

Secondly, the paper offers an account of the chronological evolution of the literature, showing unequivocally that the papers connecting these topics are very recent. The first paper evidencing this connection was published in 2015, and the bulk of the publications (more than 90\%) were published between 2018 and 2020. Despite the fact that the literature is still in its infancy, the associated scientific production is growing exponentially, vindicating the pioneering character, relevance, and timeliness of this bibliometric review and of this Special Issue.

We also found that the papers included in our extensive review are evenly distributed among paper type: $45 \%$ are empirical, $44 \%$ are theoretical, and $11 \%$ are mixed-including both theoretical and empirical contributions. 
The paper also clearly identified the most influential journal in this field. The publications surveyed were distributed among 159 scientific journals. The leading journal in this ranking was Sustainability (with 83 publications out of the original 393). The paper reported on the top 24 journals (including three or more articles each). In the ranking reported, we also provide the respective ranking according to Scopus SJR (2019) quantitative indicator (based on citations), and the scientific areas to which these top journals in the field belong.

Subsequently, the paper offered a ranking of the authors according to their number of publications in this area (including authors that wrote three or more publications in our sample-36 authors reported this ranking). Our sample included the work of 1232 authors, both alone and in co-authorship.

Then, the top 20 publications based on their number of citations were identified. This is one of the most important analyses to do in bibliometric works. Our analysis showed that there are seven publications with more than 100 citations, which is remarkable considering how recent such publications are-six are from 2018 and one is from 2017.

After that, and using different software (VOS Viewer), the paper provided a clear mapping of the network overlay of the most cited publications. The citation link of the documents was analyzed, identifying which publications cited other publications present in the sample. The network overlay reported shows the publications that were cited 25 or more times. Similar to this, the connections between the cross-cited papers were evidenced, allowing us to identify nine clusters of papers with strong links among them, as well as the papers anchoring each cluster.

Finally, this paper focused on the main topics mentioned in the surveyed publications. It carefully analyzed all keywords in all 393 publications. The range of topics was wide, and the three most frequent topics/keywords mentioned in the reviewed literature were "Industry 4.0" (284 occurrences), "Sustainability" (170), and "Sustainable Development" (115). The paper reports on all keywords displaying 10 or more occurrences. After reporting on the frequency of these topics, we went on to understand the relations between them, i.e., again using the software VOS Viewer to map the network overlay of the most frequent keywords, in order to establish links between related topics. We show that, in spite of the diversity of themes, it is possible to clearly identify four main groups or clusters, as reported in the relevant section above: (i) based on Industry 4.0 in general, linking it with sustainability; (ii) more methodological, based on systematic literature reviews/surveys, highlighting the role and relevance of big data; (iii) focused on supply chain management, logistics and IoT; and (iv) developed around digitalization and additive manufacturing.

Our findings provide a tangible contribution to understand extant literature on the key topics explored in this Special Issue-Industry 4.0, Sustainability, and the Circular Economy. This is a young field, and the literature is still in its infancy, which is no surprise as Industry 4.0 is a recent concept and is still at an early stage of implementation. The focus on sustainability and on the circular economy is also recent. Yet, the exponential growth of the literature and the significant group of publications already available warranted the pertinence of this wide-ranging and deep dive into the literature, as well as of the publication of this Special Issue. Given the newness of these topics, there are are considerable opportunities and avenues for future research, both at the theoretical and the empirical level.

First of all, data on these phenomena are not yet present in large datasets, and researchers still struggle to find appropriate elements to rely on for their research. Indeed, most empirical papers need to search for their own primary data. It would be very informative if large datasets on the implementation of Industry 4.0 and on its key features were gathered. The same comment holds for themes related to Sustainability and to the Circular Economy.

We would like to point out that we identified room for theoretical development; for instance, publications developing taxonomies or tools to classify different aspects related to these topics would be also useful. 
Last but not least, despite the fact that the themes and evidence are still recent, it would be important to develop more policy-based studies, as policy-makers are called to decide and to deploy important amounts of resources in these areas, but frameworks lack information and data to underlie evidence-based policy.

Author Contributions: Conceptualization, methodology, formal analysis, writing-original draft preparation, writing - review and editing have been conducted by both authors, C.V. and A.T.T.-L. All authors have read and agreed to the published version of the manuscript.

Funding: Ana Teresa Tavares-Lehmann would like to acknowledge that, in her case, this research has been financed by Portuguese public funds through FCT—Fundação para a Ciência e a Tecnologia, I.P., in the framework of the project with reference UIDB/04105/2020. Celeste Varum would like to acknowledge that, in her case, this work was financially supported by the research unit on Governance, Competitiveness and Public Policy (UIDB/04058/2020)+(UIDP/04058/2020), funded by national funds through FCT—Fundaçaão para a Ciência e a Tecnologia.

Conflicts of Interest: The authors declare no conflict of interest.

\section{References}

1. Dantas, T.; De-Souza, E.; Destro, I.; Hammes, G.; Rodriguez, C.; Soares, S. How the combination of Circular Economy and Industry 4.0 can contribute towards achieving the Sustainable Development Goals. Sustain. Prod. Consum. 2021, 26, 213-227. [CrossRef]

2. Bag, S.; Pretorius, J.H.C. Relationships between industry 4.0, sustainable manufacturing and circular economy: Proposal of a research framework. Int. J. Organ. Anal. 2020. [CrossRef]

3. Vrchota, J.; Pech, M.; Rolínek, L.; Bednář, J. Sustainability Outcomes of Green Processes in Relation to Industry 4.0 in Manufacturing: Systematic Review. Sustainability 2020, 12, 5968. [CrossRef]

4. $\quad$ Elkington, J. Enter the triple bottom line. In The Triple Bottom Line: Does It All Add Up; Henriques, A., Richardson, J., Eds.; Routledge: London, UK, 2004; pp. 1-16.

5. Ghobakhloo, M. Industry 4.0, digitization, and opportunities for sustainability. J. Clean. Prod. 2020, 252, 119869. [CrossRef]

6. Bressanelli, G.; Adrodegari, F.; Perona, M.; Saccani, N. Exploring How Usage-Focused Business Models Enable Circular Economy through Digital Technologies. Sustainability 2018, 10, 639. [CrossRef]

7. Kamble, S.S.; Gunasekaran, A.; Gawankar, S.A. Sustainable Industry 4.0 framework: A systematic literature review identifying the current trends and future perspectives. Process Saf. Environ. Prot. 2018, 117, 408-425. [CrossRef]

8. De Sousa Jabbour, A.B.L.; Jabbour, C.J.C.; Godinho-Filho, M.; Roubaud, D. Industry 4.0 and the circular economy: A proposed research agenda and original roadmap for sustainable operations. Ann. Oper. Res. 2018, 270, 273-286. [CrossRef]

9. Machado, C.G.; Winroth, M.P.; Da Silva, E.H.D.R. Sustainable manufacturing in Industry 4.0: An emerging research agenda. Int. J. Prod. Res. 2020, 58, 1462-1484. [CrossRef]

10. Piccarozzi, M.; Aquilani, B.; Gatti, C. Industry 4.0 in management studies: A systematic literature review. Sustainability 2018, 10, 3821. [CrossRef]

11. Rosa, P.; Sassanelli, C.; Urbinati, A.; Chiaroni, D.; Terzi, S. Assessing relations between Circular Economy and Industry 4.0: A systematic literature review. Int. J. Prod. Res. 2020, 58, 1662-1687. [CrossRef]

12. Pritchard, A. Statistical bibliography or bibliometrics. J. Doc. 1969, 25, 348-349.

13. Du, Y.; Teixeira, A.A. A bibliometric account of Chinese economics research through the lens of the China Economic Review. China Econ. Rev. 2012, 23, 743-762. [CrossRef]

14. Ferreira, M.P.; Santos, J.C.; De Almeida, M.I.R.; Reis, N.R. Mergers \& acquisitions research: A bibliometric study of top strategy and international business journals, 1980-2010. J. Bus. Res. 2014, 67, 2550-2558. [CrossRef]

15. Hood, W.W.; Wilson, C.S. The Literature of Bibliometrics, Scientometrics, and Informetrics. Scientometrics 2001, 52, 291-314. [CrossRef]

16. Cobo, M.; Martínez, M.; Gutiérrez-Salcedo, M.; Fujita, H.; Herrera-Viedma, E. 25years at Knowledge-Based Systems: A bibliometric analysis. Knowl.-Based Syst. 2015, 80, 3-13. [CrossRef]

17. De Oliveira, O.J.; Da Silva, F.F.; Juliani, F.; Barbosa, L.C.F.M.; Nunhes, T.V. Bibliometric Method for Mapping the State-of-the-Art and Identifying Research Gaps and Trends in Literature: An Essential Instrument to Support the Development of Scientific Projects. In Scientometrics Recent Advances; Kunosic, S., Zerem, E., Eds.; IntechOpen: London, UK, 2019. [CrossRef]

18. Manriquez, J.; Andino-Navarrete, R.; Cataldo-Cerda, K.; Harz-Fresno, I. Bibliometric characteristics of systematic reviews in dermatology: A cross-sectional study through Web of Science and Scopus. Dermatol. Sin. 2015, 33, 154-156. [CrossRef]

19. Teixeira, A.A.C. Evolution, roots and influence of the literature on National Systems of Innovation: A bibliometric account. Camb. J. Econ. 2014, 38, 181-214. [CrossRef]

20. Archambault, É.; Gagné, É.V. The Use of Bibliometrics in the Social Sciences and Humanities; Science-Metrix Final Report; ScienceMetrix: Montreal, QC, Canada, 2004. 
21. Martín-Martín, A.; Orduna-Malea, E.; Thelwall, M.; López-Cózar, E.D. Google Scholar, Web of Science, and Scopus: A systematic comparison of citations in 252 subject categories. J. Inf. 2018, 12, 1160-1177. [CrossRef]

22. Parida, V.; Sjödin, D.; Reim, W. Reviewing Literature on Digitalization, Business Model Innovation, and Sustainable Industry: Past Achievements and Future Promises. Sustainability 2019, 11, 391. [CrossRef]

23. Falagas, M.E.; Pitsouni, E.I.; Malietzis, G.A.; Pappas, G. Comparison of PubMed, Scopus, Web of Science, and Google Scholar: Strengths and weaknesses. FASEB J. 2007, 22, 338-342. [CrossRef]

24. Archambault, É.; Campbell, D.; Gingras, Y.; Larivière, V. Comparing bibliometric statistics obtained from the Web of Science and Scopus. J. Am. Soc. Inf. Sci. Technol. 2009, 60, 1320-1326. [CrossRef]

25. Kelly, J.; Sadeghieh, T.; Adeli, K. Peer Review in Scientific Publications: Benefits, Critiques, \& A Survival Guide. EJIFCC 2014, 25, 227-243. [PubMed]

26. Ejsmont, K.; Gladysz, B.; Kluczek, A. Impact of Industry 4.0 on Sustainability-Bibliometric Literature Review. Sustainability 2020, 12, 5650. [CrossRef]

27. SCImago. 2020. Available online: www.scimagojr.com (accessed on 25 December 2020).

28. Bakkalbasi, N.; Bauer, K.; Glover, J.; Wang, L. Three options for citation tracking: Google Scholar, Scopus and Web of Science. Biomed. Digit. Libr. 2006, 3, 7. [CrossRef] [PubMed]

29. Luthra, S.; Mangla, S.K. Evaluating challenges to Industry 4.0 initiatives for supply chain sustainability in emerging economies. Process Saf. Environ. Prot. 2018, 117, 168-179. [CrossRef]

30. Chauhan, C.; Singh, A.; Luthra, S. Barriers to industry 4.0 adoption and its performance implications: An empirical investigation of emerging economy. J. Clean. Prod. 2021, 285, 124809. [CrossRef]

31. Luthra, S.; Kumar, A.; Zavadskas, E.K.; Mangla, S.K.; Garza-Reyes, J.A. Industry 4.0 as an enabler of sustainability diffusion in supply chain: An analysis of influential strength of drivers in an emerging economy. Int. J. Prod. Res. 2020, 58, 1505-1521. [CrossRef]

32. Bag, S.; Yadav, G.; Wood, L.C.; Dhamija, P.; Joshi, S. Industry 4.0 and the circular economy: Resource melioration in logistics. Resour. Policy 2020, 68, 101776. [CrossRef]

33. Bag, S.; Wood, L.C.; Mangla, S.K.; Luthra, S. Procurement 4.0 and its implications on business process performance in a circular economy. Resour. Conserv. Recycl. 2020, 152, 104502. [CrossRef]

34. Müller, J.M.; Kiel, D.; Voigt, K.-I. What Drives the Implementation of Industry 4.0? The Role of Opportunities and Challenges in the Context of Sustainability. Sustainability 2018, 10, 247. [CrossRef]

35. Kiel, D.; Müller, J.M.; Arnold, C.; Voigt, K.I. Sustainable industrial value creation: Benefits and challenges of industry 4.0. Int. J. Innov. Manag. 2017, 21, 1740015. [CrossRef]

36. Birkel, H.S.; Veile, J.W.; Müller, J.M.; Hartmann, E.; Voigt, K.-I. Development of a Risk Framework for Industry 4.0 in the Context of Sustainability for Established Manufacturers. Sustainability 2019, 11, 384. [CrossRef]

37. Durieux, V.; Gevenois, P.A. Bibliometric Indicators: Quality Measurements of Scientific Publication. Radiology 2010, $255,342-351$. [CrossRef]

38. Raut, R.D.; Mangla, S.K.; Narwane, V.S.; Gardas, B.B.; Priyadarshinee, P.; Narkhede, B.E. Linking big data analytics and operational sustainability practices for sustainable business management. J. Clean. Prod. 2019, 224, 10-24. [CrossRef]

39. Waibel, M.W.; Steenkamp, L.P.; Moloko, N.; Oosthuizen, G.A. Investigating the effects of Smart Production Systems on sustainability elements. Procedia Manuf. 2017, 8, 731-737. [CrossRef]

40. Sjödin, D.R.; Parida, V.; Leksell, M.; Petrovic, A. Smart Factory Implementation and Process Innovation. Res. Manag. 2018, 61, 22-31. [CrossRef]

41. Manavalan, E.; Jayakrishna, K. A review of Internet of Things (IoT) embedded sustainable supply chain for industry 4.0 requirements. Comput. Ind. Eng. 2019, 127, 925-953. [CrossRef]

42. Ding, B. Pharma Industry 4.0: Literature review and research opportunities in sustainable pharmaceutical supply chains. Process Saf. Environ. Prot. 2018, 119, 115-130. [CrossRef]

43. Yadav, G.; Luthra, S.; Jakhar, S.K.; Mangla, S.K.; Rai, D.P. A framework to overcome sustainable supply chain chal-lenges through solution measures of industry 4.0 and circular economy: An automotive case. J. Clean. Prod. 2020, 254, 120112. [CrossRef]

44. Strandhagen, J.O.; Vallandingham, L.R.; Fragapane, G.; Strandhagen, J.W.; Stangeland, A.B.H.; Sharma, N. Logistics 4.0 and emerging sustainable business models. Adv. Manuf. 2017, 5, 359-369. [CrossRef]

45. Dev, N.K.; Shankar, R.; Qaiser, F.H. Industry 4.0 and circular economy: Operational excellence for sustainable reverse supply chain performance. Resour. Conserv. Recycl. 2020, 153, 104583. [CrossRef]

46. Mehrpouya, M.; Dehghanghadikolaei, A.; Fotovvati, B.; Vosooghnia, A.; Emamian, S.S.; Gisario, A. The potential of additive manufacturing in the smart factory industrial 4.0: A review. Appl. Sci. 2019, 9, 3865. [CrossRef]

47. Murmura, F.; Bravi, L. Additive manufacturing in the wood-furniture sector: Sustainability of the technology, benefits and limitations of adoption. J. Manuf. Technol. Manag. 2018, 29, 350-371. [CrossRef]

48. Stentoft, J.; Philipsen, K.; Haug, A.; Wickstrøm, K.A. Motivations and challenges with the diffusion of additive manufacturing through a non-profit association. J. Manuf. Technol. Manag. 2020. [CrossRef] 